\title{
A STUDY ON THE ACUTE TOXICITY OF QUERCETIN SOLID DISPERSION AS A POTENTIAL NEPHRON-PROTECTOR
}

\author{
H. Lucida ${ }^{1, *}$, Y. Primadini' ${ }^{2}$ and Suhatri ${ }^{2}$ \\ ${ }^{1}$ Department of Pharmaceutics, Faculty of Pharmacy, University of Andalas, Indonesia \\ ${ }^{2}$ Department of Pharmacology, Faculty of Pharmacy, University of Andalas, Indonesia \\ *E-mail : hennylucida@phar.unand.ac.id, hennylucida@gmail.com
}

\begin{abstract}
Quercetin has been used in combination with other nutraceutical components to improve renal function. Its development as an active pharmaceutical ingredient, however, is limited by poor aqueous solubility and low rate of dissolution.Solid dispersion of quercetin with polyvinylpyrrolidoneK30 increased its solubility 13.24 times and the amount dissolved $(95.12 \pm 1.83) \%$ compared to pure quercetin. This study aimed to determine the lethal dose $\left(\mathrm{LD}_{50}\right)$ of the solid dispersion in mice. The animals were divided into 5 groups, a control group (G1), and treatment groups given quercetin solid dispersions at the doses of 2 (G2), 4(G3), 8(G4), and $16 \mathrm{~g} / \mathrm{kg}$ (G5), respectively. The observation was conducted for 24 hours, and every day for 14 days if no death was found. Results showed that there was no animal found dead during the first 24 hours. The treatment did not influence the average bodyweight significantly $(\mathrm{p}>0.05)$, but it significantly influenced the feeding behavior $(\mathrm{p}<0.05)$. The organ weight ratios of heart, liver and renal were not influenced significantly $(\mathrm{p}>0.05)$, despite there was a decrease in renal function at doses of 8 and $16 \mathrm{~g} / \mathrm{kg}$. In conclusion, the solid dispersion was practically non-toxic with the $\mathrm{LD}_{50}>16 \mathrm{~g} / \mathrm{kg}$.

Keywords: Quercetin, Solid Dispersion, Acute Toxicity, LD 50.
\end{abstract}

(C) RASĀYAN. All rights reserved

\section{INTRODUCTION}

The prevalence of Chronic Kidney Disease(CKD) in Indonesia increased 40\% per year as released by the Association of Indonesian Nephrologist ${ }^{1}$. In 2016, there are about 42 million CKD patients, the number might keep increasing next years as data from the World Health Organization (WHO) showed that the number of diabetes mellitus patients in Indonesia are in the $4^{\text {th }}$ ranked in the world ${ }^{1,2}$. Age-related diseases such as diabetes mellitus, hypertension, and cardiovascular diseases are known as the main causes of deteriorated renal function besides the long term used of nephrotoxic drugs ${ }^{3,4}$. A compound called a nephron-protector has not yet been recognized, although a hepato-protector is well-known to protect the liver from damages ${ }^{5,6}$.A nephron-protective compound is expected to delay the progress of renal function deterioration so as to enhance the quality of life of patients who already diagnosed with the diseases.

Some naturally derived compounds have been reported to show an effect on improving renal function. Quercetin $(500 \mathrm{mg}$ ) in combination with vitamin C, vitamin B3, and folic acid has been reported to improve the renal function of human subjects ${ }^{7}$. The co-administration of quercetin $(50 \mathrm{mg} / \mathrm{kg})$ with cisplatin (4 mg/kg) to Mat B-III breast adenocarcinoma rats was able to prevent renal impairment caused by the chemotherapeutic agent ${ }^{8}$. Another study showed that quercetin at an oral dose of $10 \mathrm{mg} / \mathrm{kg}$ per day for 4 weeks showed a beneficial effect in the prevention and the treatment of renal dysfunction caused by diabetes mellitus ${ }^{9}$.

Quercetin tablets $(500 \mathrm{mg}$ ) are available in the market as a food supplement with a claim as an antioxidant. The development of quercetin as an active pharmaceutical ingredient is limited by poor aqueous solubility and low rate of dissolution leading to low bioavailability ${ }^{10}$. Our preliminary study showed an increased in quercetin solubility and its dissolution rate by preparation of solid dispersion to yield submicron quercetin particles ${ }^{11}$. The increase in dissolution rate correlates with an increase in the

Rasayan J. Chem., 12(2), 727-732(2019)

http://dx.doi.org/10.31788/RJC.2019.1224068

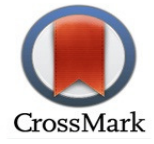


bioavailability and in turn a reduction in quercetin effective dose. This study aimed to determine the lethal dose $\left(\mathrm{LD}_{50}\right)$ of the solid dispersion in mice.

\section{EXPERIMENTAL}

Material and Methods

Quercetin (Sigma), quercetin solid dispersion (QSD) with polyvinylpyrrolidone(PVP) K30 (1:9) obtained from the Laboratory of Physical Pharmacy University of Andalas, tween 80 (Bratachem ${ }^{\circledR}$ ), NaCl $0.9 \%$ (Otsuka ${ }^{\circledR}$ ), formalin solution 10\% (PT. Arjuna Utama Kimia), hematoxylin-eosin stains (Himedia), Mayer's albumin (PT. Indo Achitama Chemical Industry), ethanol (Bratachem ${ }^{\circledR}$ ), paraffin (PT. Kirana Mitra Abadi), xylene (PT. Anugrah Putra Kencana) and Dyasis ${ }^{\circledR}$ (Dyasis Diagnostic System Gmbh).

\section{Animal Preparation}

Male white mice (Mus musculus strain DDY)weighing 20-30 gram were obtained from the Veterinary Office of Bukittinggi. The animals were kept under observation for acclimatization before treatments. The selected animals were placed in plastic cages at the normal temperature $\left(24 \pm 2^{\circ} \mathrm{C}\right)$ and 12 hours light/dark cycle. They were given access to drinking water and a standard diet. All animal handling procedures were done with the approval of the Animal Ethics Committee of the Faculty of Medicine, University of Andalas (document no. 210/KEP/FK/2017 on July $3^{\text {rd }}, 2017$ ).

\section{Acute Toxicity Test of QSD}

A screening study was conducted at an oral dose of $1000 \mathrm{mg} / \mathrm{kg}$ BW QSD (equivalent to $100 \mathrm{mg} / \mathrm{kg}$ quercetin) given to a mouse. The animals were observed for behavioral changes and death under 24-hour. The results of this study were used as the baseline dose for further evaluation.

After 7 days of acclimatization, the animals $(n=25)$ were randomly distributed into 5 groups. Group 1 (G1) was a control group, receives water, standard food and a vehicle (2\% tween 80 solutions). Groups G2, G3, G4, and G5 were given standard food, water, and QSD suspension in the vehicle at oral doses of $2,4,8$ and $16 \mathrm{~g} / \mathrm{kg}$, respectively. The observation was carried out for 24 hours, and daily for 14 days if no death was found.

During treatment, all the mice were weighed and observed for toxicity related signs such as changes in skin and fur, eyes, mucous membrane, patterns of behavior, respiratory rate, sensitivity to noise, the amount of food consumption, drinking behavior, and body weight, as well as the occurrence of diarrhea, tremors, convulsions or death.

After day $14^{\text {th }}$, the mice were fasted for 12 hours and sacrificed. The blood was collected from the carotid artery and stored in a tube for 15 minutes, then centrifuged at $3000 \mathrm{rpm}$ for 20 minutes, the serum was taken and kept frozen until being analyzed for the creatinine level.

Histopathology test was conducted to death mice ${ }^{12}$. The heart, the liver, and the kidney were cut, weighed and washed with $0.9 \% \mathrm{NaCl}$, the organs were kept in a refrigerator until used for histology observations.

For histological examination, all the vital organs were fixed in $10 \%$ formalin, dehydrated by passing through the alcohol solution at decreasing concentration and cleared with alcohol and xylene ${ }^{12}$. The tissue was then embedded in liquid paraffin and left frozen. It was sliced with a microtome to obtain a tissue section with a thickness of $5 \mu \mathrm{m}$. The tissue sections were stained in Hematoxylin and Eosin ${ }^{13}$, they were then mounted for microscopic observation (Carl Zeiss®, Germany).

\section{Statistical Analysis}

Data are shown as mean \pm standard deviation, analyzed by two-way ANOVA $(\alpha=0.05)$ to establish the significant differences between means followed by the Duncan Multiple Range Test at 5\% significance level.

\section{RESULTS AND DISCUSSION}

Quercetin is a naturally occurring flavonoid found in fruits and vegetables which is safe to consume and has numerous health benefits to humans. ${ }^{14,15}$ Quercetin tablet at a dose of $500 \mathrm{mg}$ is marketed in the US as a food supplement. It is claimed as an antioxidant which obtains protection against oxidative damages due to reactive oxygen species (ROS) and correlates well with prevention from cardiovascular diseases, diabetes mellitus and cancer. ${ }^{16,17}$ In an attempt to develop quercetin as a potential nephron-protector, we 
formulated quercetin solid dispersion which increased its aqueous solubility as well as the dissolution rate $^{11,18}$. Further, acute toxicity of the solid dispersion should be evaluated to ensure the safety and effectiveness of the formulation ${ }^{19}$.

In this study, the dose was designed based on the up and down method ${ }^{20}$. There was no mortality occurred after an oral dose of $1000 \mathrm{mg} / \mathrm{kg} \mathrm{BW}$ to a mouse within 24 hours. Therefore, for the main study, doses multiplied by 2 were chosen, started from 2; $4 ; 8$ and $16 \mathrm{~g} / \mathrm{kg}$. Results showed that no animal was dead at all doses after 24 hours, the mice were under observation for any toxicity-related signs within the first four hours after the treatment and daily for 14 days. There is no mortality observed up to the maximum dose level used in this study indicates that the solid dispersion has an $\mathrm{LD}_{50}>16 \mathrm{~g} / \mathrm{kg} \mathrm{BW}$ which is considered to be practically non-toxic ${ }^{21}$.

Observation on toxicity-related signs (Table-1) showed changes in the respiratory rate, sensitivity to sound, behavior signs such as apathy and food uptake on treatment groups. Tremors occurred in all treatment groups. Data showed that food consumption of treatment groups was significantly affected by dosing, however, there was no significant difference in the water consumption between control and treatment groups. Doses 8 and $16 \mathrm{~g} / \mathrm{kg}$ caused significant changes in the respiratory rate, dose $16 \mathrm{~g} / \mathrm{kg}$ showed that the animals were less sensitive to sound. There were no significant changes in the body weight, no convulsions observed and no changes in the eyelid closure.

Table-1: Observations of Toxicity-related Signs

\begin{tabular}{c|c|c|c|c|c|c}
\hline No. & Toxicity Related Signs & $\mathrm{G} 1$ & $\mathrm{G} 2$ & $\mathrm{G} 3$ & $\mathrm{G} 4$ & $\mathrm{G} 5$ \\
\hline 1 & Skin and fur & $\mathrm{N}$ & $\mathrm{N}$ & $\mathrm{N}$ & $\mathrm{N}$ & $\mathrm{N}$ \\
\hline 2. & Eyes & $\mathrm{N}$ & $\mathrm{N}$ & $\mathrm{N}$ & $\mathrm{N}$ & $\mathrm{N}$ \\
\hline 3. & Mucous membrane & $\mathrm{N}$ & $\mathrm{N}$ & $\mathrm{N}$ & $\mathrm{N}$ & $\mathrm{N}$ \\
\hline 4. & Patternsof behavior & $-*$ & $-*$ & $-*$ & $+*$ & $+*$ \\
\hline 5. & Increase in respiratory rate & - & - & - & - & - \\
\hline 6. & Diarrhea & - & - & - & - & + \\
\hline 7. & Decreased sensitivity to sound & - & + & + & + & + \\
\hline 8. & Tremors & - & - & - & - & - \\
\hline 9. & Convulsions & $-*$ & $+*$ & $+*$ & $+*$ & $+*$ \\
\hline 10. & Change in food uptake & $-*$ & $-*$ & $-*$ & $-*$ & $-*$ \\
\hline 11. & Change in water uptake & $-*$ & $-*$ & $-*$ & $-*$ & $-*$ \\
\hline 12. & Change in bodyweight & - & + & + & + \\
\hline N) & Change noticed (+) change & - & + & + \\
\hline
\end{tabular}

Note: (N) normal; (-) no change noticed; (+) changes noticed; (-*) no significant changes $(\mathrm{p}>0,05) ;(+*)$ significant changes $(\mathrm{p}<0,05)$

Changes in the respiratory rate, feeding behavior, and the body weight are indications of acute toxic symptoms occurred underexposure of toxicants ${ }^{21}$. An increase in the respiratory rate may be due to hypoxia which stimulates the peripheral chemoreceptors of the carotid and aortic bodies to send an impulse to the medulla oblongata and subsequently increase the respiratory rate ${ }^{22}$. The amount of food and water consumed decreases with increasing doses might correlate with a toxic manifestation of the drug given, this usually influences the rate of growth of the mice and consequently the bodyweight. In this study, only the food consumed decreases, which suggests the influence of QSD on the appetite or indication of its metabolic pharmacodynamic effects ${ }^{23}$. A chronic toxicity study with monitoring on feeding behavior after administration of QSD is needed to confirm this effect. Considering that no death occurred and no significant effects on the body weight, QSD is not acutely toxic when given orally to mice at a single dose of 2, 4, 8 and $16 \mathrm{~g} / \mathrm{kg}$ which equivalent to quercetin content of $200,400,800$ and $1600 \mathrm{mg} / \mathrm{kg}$, respectively.

Table-2 shows the effect of the treatment on the relative organ weight of the mice. The relative weight of the heart is not significantly affected by treatments, but photomicrograph of the heart tissue at doses 2,4 , 8 and $16 \mathrm{~g} / \mathrm{kg}$ (Fig.-1) indicates the occurrence of pyknosis of cell nucleus and atrophy of myocardium. The heart is an organ that is very susceptible to undesired effects of chemical compounds. The presence of exposure of toxins in the heart might lead to the reduced blood supply, blood volume and pressure in 
RASĀYAN J. Chem.

Vol. 12 | No. 2 |727 - 732| April - June | 2019

the blood vessels of the heart. As a consequence, the contraction and cardiac output decreases, then the heart will adapt to decreasing the size and the number of cells known as atrophy ${ }^{22}$.

Table-2: The Effect of Oral Administration of Quercetin Solid Dispersion on Relative Organ Weight and Serum Creatinine Level $(\mathrm{mg} / \mathrm{dL})$ of Mice

\begin{tabular}{c|c|c|c|c}
\hline \multirow{2}{*}{ Group } & \multicolumn{4}{|c}{ Mean $\pm \mathrm{SD}(\mathrm{n}=5)$} \\
\cline { 2 - 5 } & Heart & Liver & Kidney & Serum creatinine \\
\hline G1 & $0,0050 \pm 0,0005$ & $0,0851 \pm 0,0040$ & $0,0169 \pm 0,0008$ & $0,4400 \pm 0,2607$ \\
\hline G2 & $0,0055 \pm 0,0005$ & $0,0856 \pm 0,0064$ & $0,0163 \pm 0,0022$ & $0,6000 \pm 0,2828$ \\
\hline G3 & $0,0053 \pm 0,0004$ & $0,0919 \pm 0,0078$ & $0,0162 \pm 0,0009$ & $0,8000 \pm 0,3162$ \\
\hline G4 & $0,0050 \pm 0,0001$ & $0,0897 \pm 0,0039$ & $0,0170 \pm 0,0010$ & $1,0800 \pm 0,5215$ \\
\hline G5 & $0,0053 \pm 0,0006$ & $0,0928 \pm 0,0110$ & $0,0159 \pm 0,0008$ & $4,1600 \pm 1,9099^{*}$ \\
\hline
\end{tabular}

(*) denotes a significant difference in serum creatinine level of G5 versus other groups

The relative weight of the liver is not significantly affected by treatments (Table 2), however, the histopathologic analysis of liver tissue shows lysis of the endothelial cell of central veins and shrinkage of hepatocytes at the dose of $2 \mathrm{~g} / \mathrm{kg}$. Moreover, higher doses of QSD show worse effects including lysis, necrosis, and congestion of the endothelial cell of central veins, shrinkage of hepatocytes, dilatation, and bleeding of sinusoids. Changes in the histological features of the liver are the manifestation of druginduced hepatic injury. The liver is a vital organ responsible for the metabolism of drugs and toxicants, consequently, it is at high risk of damages caused by the substances or toxic metabolites ${ }^{24}$.

The effect of QSD on the safety of kidney is observed through the measurement of serum creatinine levels in mice (Table 2). The serum creatinine level of the control group is within the normal range, confirmed by microscopic observations of renal cells showing normal glomeruli, and intact Bowman's spaces (Figure1). Serum creatinine levels of the treatment groups increase with increasing dose. The serum creatinine levels of doses 2 and $4 \mathrm{~g} / \mathrm{kg}$ groups remains within the normal range. However microscopic observation of renal cells showed glomerular atrophy, widening of Bowman's space as well as proximal tubular degeneration, and lysis. Serum creatinine levels of doses 8 and $16 \mathrm{~g} / \mathrm{kg}$ are above the normal levels that indicate deteriorated renal function. This is confirmed by microscopic observation of renal tissue in which there is glomerular atrophy, widening of Bowman's space, distal tubular degeneration, proximal tubular degeneration, and lysis. Statistically, treatment does not influence the relative weights of renal organs significantly $(\mathrm{p}>0.05)$, but it significantly affects the serum creatinine levels $(\mathrm{p}<0.05)$.

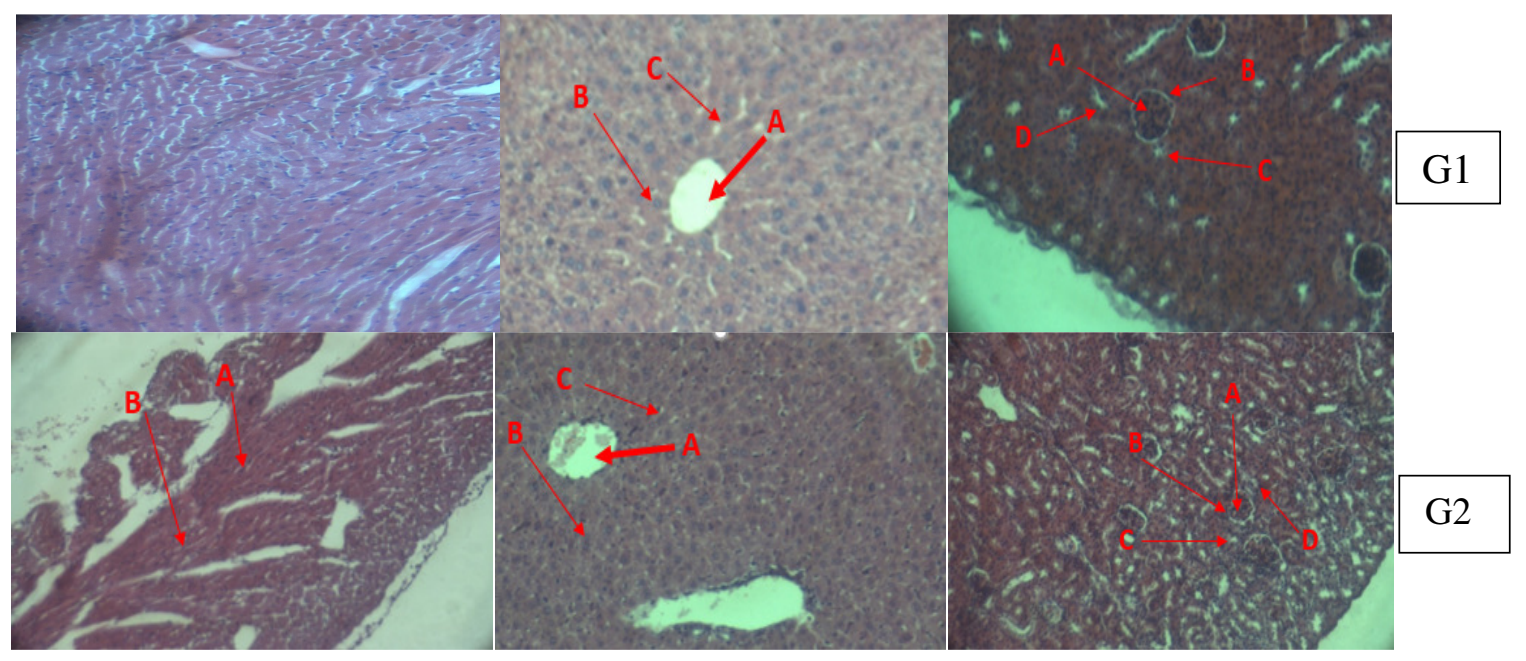




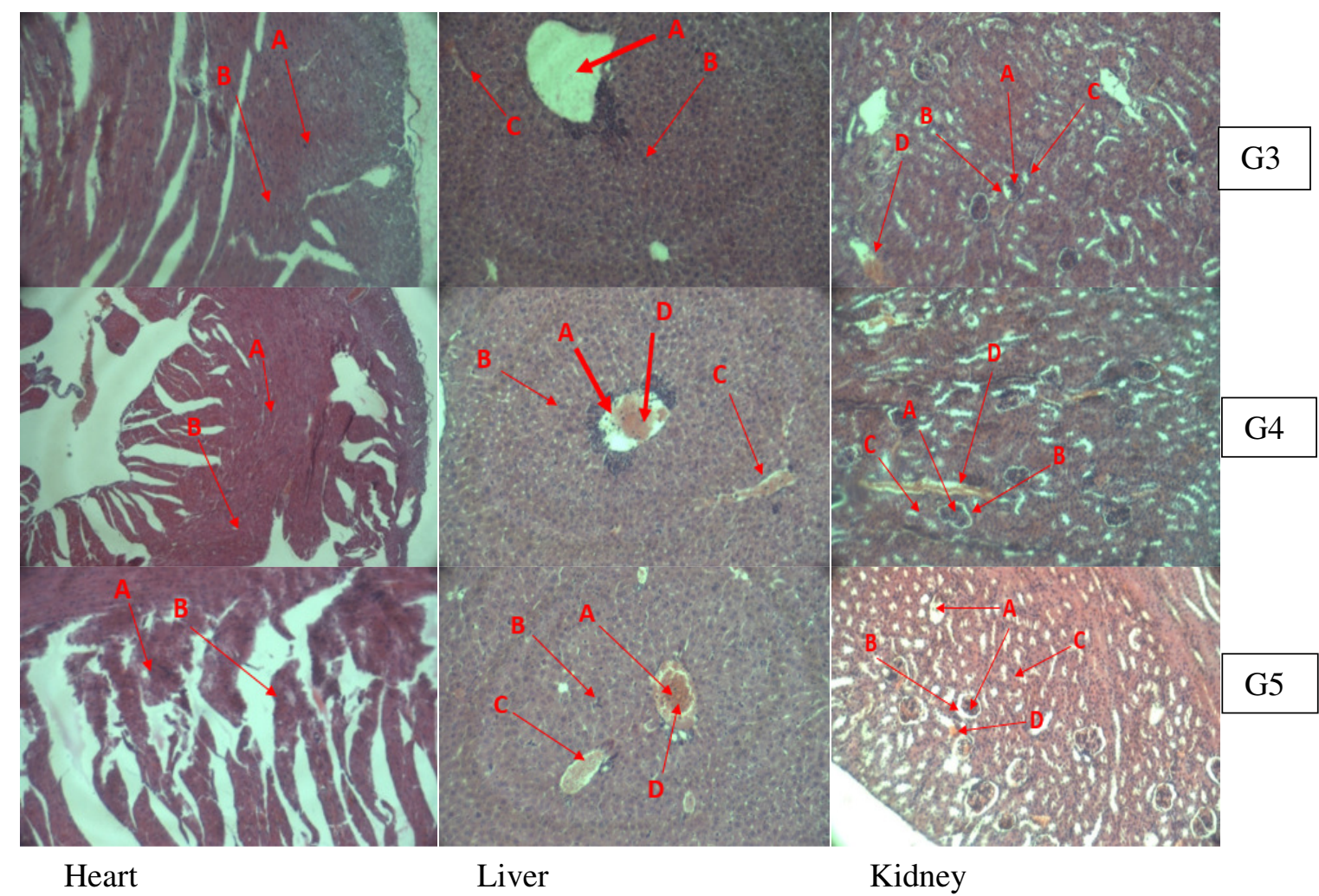

Fig.-1: Hematoxylin and Eosin Staining of the Heart, the Liver and the Kidney Sections of Control (G1) and Treated Mice at Dose 2 (G2), 4 (G3), 8 (G4) and $16 \mathrm{~g} / \mathrm{kg}$ (G5) QSD. (The Heart: A= Pyknosis; B= Atrophy of Myocardium occurred; 400x) (The Liver: A= Central Vein; $B=$ Hepatocyte; $C=$ Sinusoids and D= Haemorrhage occurred; 400x),

(The Kidney: A= Glomerulus; $\mathrm{B}=$ Bowman Space; $\mathrm{C}=$ Tubulus Distal and $\mathrm{D}=$ Tubulus Proximal; 100x)

The current study shows that administration of QSD at doses of 2, 4, 8, and $16 \mathrm{~g} / \mathrm{kg}$ unexpectedly decreases the renal function, moreover at higher doses (8 and $16 \mathrm{~g} / \mathrm{kg}$ ) cause renal damages. Pharmacokinetic study of quercetin shows that $46.7 \%-106.2 \%$ of doses given are renal excreted ${ }^{25,}{ }^{26}$. These indicate that quercetin has a high renal affinity, higher doses increase renal workload and lead to a decline of renal function. Our study on the effective dose of QSD as nephron-protector showed a much lower effective dose of $100 \mathrm{mg} / \mathrm{kg}$ QSD or equivalent to $10 \mathrm{mg}$ quercetin.

\section{CONCLUSION}

QSD is not acutely toxic when given orally to mice at the single dose of $2,4,8$ and $16 \mathrm{~g} / \mathrm{kg}$ which equivalent to quercetin content of $200,400,800$ and $1600 \mathrm{mg} / \mathrm{kg}$, respectively. The $\mathrm{LD}_{50}$ of QSD is > 16 $\mathrm{g} / \mathrm{kg}$ and it is practically non-toxic. A chronic toxicity test is required to confirm the effect of QSD doses on the safety of main organs such as the heart, liver, and kidneys.

\section{ACKNOWLEDGMENT}

The authors acknowledged University of Andalas for financial support through a research grant Contract No. 10/UN.16.17/PP.HGB/LPPM/2017.

\section{REFERENCES}

1. W. Prodjosudjadi, Suhardjono, K. Suwitra, Pranawa, I.G. Widiana, J.S. Loekman, G. Nainggolan, H. Prasanto, Y. Wijayanti, Dharmeizar, M. Sja'bani, M.Y. Nasution, W. Basuki, Aditiawardana, D.C. Harris, D.J. Pugsley, Nephrology.,14(7), 669 (2009), DOI: 10.1111/j.1440-1797.2009.01137.x.

2. The Ministry of Health Republic of Indonesia, Profil Kesehatan Indonesia Tahun 2016, 2017, Kementrian Kesehatan Republik Indonesia, Jakarta, p.5. 
RASĀYAN J. Chem.

Vol. 12 | No. 2 |727 - 732| April - June | 2019

3. N. R.Hill, S.T. Fatoba, J.L. Oke, J.A. Hirst, C.A. O'Callaghan, D.S. Lasserson, F.D.R.Hobbs, PLos One, 11(7), (2016), DOI:10.1371/journal.pone.0158765

4. R.T. Gansevoort, R. Correa-Rotter, B.R. Hemmelgarn, T.H. Jafar, H.J. Heerspink, J.F. Mann, Lancet. 382(9889), 339 (2013), DOI:10.1016/S0140-6736(13)60595-4

5. R.A. Al-Eisa, H.I. Khouja,H.A. Al-Nahari, Int. J. Pharm. Res. Allied Sci., 6(2), 110 (2017).

6. B. Cahyono, J. Ariani, H. Failasufa, M. Suzery, S. Susanti and H. Hadiyanto, Rasayan J. Chem., 12(1), 7 (2019), DOI: 10.31788/RJC.2018.1144076

7. T.C. Lines, US PatentUS 8,680,053 B2 (2014).

8. M.E.O. Aldemir, K. Kösemehmetoğlu, K. Ener, F. Topal, O. Evirgen, A.Avc1, Andrologia, 1, 1 (2014), DOI:10.1111/and.12197

9. I.B.S. Gomes, M.L. Porto, M.C. Santos, B.P. Campagnaro, T. Pereira, S.S. Meyrelles,E.C. Vasquez, Lipids in Health and Dis., 13, 184 (2014), DOI: 10.1186/1476-511X-13-184

10. X. Cai, Z. Fang, J. Dou, A. Yu, G.Zhai,Current Med. Chem., 20, 2572 (2013), DOI: 1875-533X/13

11. H. Lucida,Suhatri, Febriyenti and Erizal, Indonesia Patent Registration No. PID 201803024 (2018).

12. OECD Guideline for Testing of Chemical 425. Acute Oral Toxicity-Up and Down Procedure. Paris, OECD Environment Directorate, Environment, Health and Safety Division (2008).

13. J.G.A. Mcmanus, R.W. Mowry, 1984, Staining Methods: Histological and Histochemical, Harper and Row, New York.

14. L. Hooper, P.A. Kroon, E.B. Rimm,Am. J. Clin.Nutr.,88, 38 (2008), DOI: 10.1093/ajcn/88.1.38

15. E.M. Widyasari, M.Y.A Simarmata, M. Marzuki, M.E.Sriyani, R.J.Sugiharti and W. Nuraeni, Rasayan J. Chem., 12(1), 278 (2019), DOI: 10.31788/RJC.2019.1215052

16. L. Wang, I.M. Lee, S.M. Zhang,Am. J. Clin.Nutr.,89, 905 (2009), DOI: 10.3945/ajen.2008.26913.

17. R.I. Zamora-Ros, M. Rabassa, A. Cherubini, M. Urpí-Sardà, S. Bandinelli, L. Ferrucci, C. AndresLacueva, J.Nutr.,143, 1445 (2013), DOI: 10.3945/jn.113.177121

18. H. Lucida, Febriyenti, R. Pradana, L. Rahmatika, Der Pharm. Lett., 8(18), 53 (2016).

19. B.V. Udugadeand S. P. Gawade, Rasayan J. Chem., 11(1), 118(2018), DOI: 10.7324/RJC.2018.1111860.

20. ICCVAM-Recommended Test Method Protocol. The Up-and-Down Procedure for Acute Oral Systemic Toxicity, NIH Publication No. 02-4501 (2001). Available from: http://iccvam. niehs.nih.gov/methods /acutetox/udp_report.htm

21. F.C. Lu, S. Kacew, Lu's Basic Toxicology, Fundamental, Target Organs and Risk Assessment, 1985, $4^{\text {th }}$ ed., Taylor \& Frances, New York.

22. Sherwood, L., 2014, Human Physiology: From Cells to Systems., $9^{\text {th }}$ edition, Cengage learning, p.514.

23. M. Todi, S. Baki, B. Begovi, S. Kronjar, I. Zuli, Bosnian J. Basic Med. Sci. III, 4, 47 (2003).

24. R. Ramachandran, S. Kakar, Histological Patterns in Drug-induced Liver Disease, J. Clin. Pathol., 62, 481 (2009), DOI:10.1136/jcp.2008.058248

25. I. Erlund, T. Kosonen, G. Alfthan, J. Maenpaa, K. Perttunen, J. Kenraali, A. Aro, Eur.J. Clin. Pharmacol., 56, 545 (2000).

26. Y.J. Moon, L. Wang, R.D. Cenzo, M.E. Morris, Biopharm. Drug Disp., 29, 205 (2008), DOI: 10.1002/bdd. 605

[RJC-4068/2018] 